\title{
Translating Subtitles - Translating Cultures
}

\author{
Evgeniya D. Malenova* \\ Omsk State University n.a. F.M. Dostoyevsky \\ 55a Mira, Omsk, 644077, Russia
}

Received 05.10.2015, received in revised form 29.10.2015, accepted 18.11.2015

The paper focuses upon the problem of trans-cultural transfer in subtitling as a type of audiovisual translation. The methodology of the research involves analysis of the key procedures used for translating culture-specific concepts taking into consideration the principles of dynamic equivalence and the restrictions, applied to the text and the translator in the course of subtitling. The author defines these restrictions and argues their nature. Special attention is payed to the challenges of the audiovisual translation determined by specificity of trans-cultural transfer. As the result, the author brings to light the key strategies of subtitling audiovisual products containing culture-specific concepts and historically marked culture-specific slang Considering that audiovisual content is a polycode text. The results can be used in applied and theoretical translation practice, as a guide in subtitling practice, as a tool for teaching audiovisual translation.

Keywords: AV-translation, subtitling, culture-specific concept, source language, target language, trans-cultural transfer, dynamic equivalence.

DOI: 10.17516/1997-1370-2015-8-12-2891-2900.

Research area: philology.

\section{Introduction}

Translation studies has been a major issue for the last two decades; now we face a dramatic increase of the amount of research connected with different issues of translation. What has triggered such an upsurge? Here is a simple explanation it has actually been an upswing of demand for translation services, accompanied with a decrease in the overall quality of translation. The area of translation suffering the most is an Audiovisual Translation (AVT). According to Alexei Kozulyaev, for a long time translation of films, TV-programs and computer games being blends of verbal and non-verbal systems of information coding was considered a part of a literary or simultaneous translation (Козуляев, 2014). Thus, the strategies of literary translation were unsuccessfully applied to an audiovisual content; that resulted in major quality deterioration. Now most foreign and some Russian linguists argue that AVT is a separate type of translation with its own rules, peculiarities and restrictions.

AVT is usually divided into two major fields: dubbing and subtitling. Dubbing is an oral presentation of the translated script, though subtitling involves superimposing of the translated text onto the screen. Both types of AVT are very interesting and having their own issues, although

(C) Siberian Federal University. All rights reserved

* Corresponding author E-mail address: malenovae@mail.ru 
in the auspices of the present research I would like to focus on subtitling.

Jorge Diaz Cintas and Aline Remael define subtitling as "a translation practice that consists of presenting a written text, generally on the lower part of the screen, that endeavors to recount the original dialogue of the speakers, as well as the discursive elements that appear in the image (letters, inserts, graffiti, inscriptions, placards, and the like), and the information that is contained on the soundtrack (songs, voices off) (Diaz Cintas, Remael, 2007). Such a complicity of subtitles imposes a lot of restrictions upon a translator; on the other hand subtitles should trigger a target audience's reaction similar to the one of the source audience. That is why the problem of subtitling is a vexed one; besides there is a great amount of the so-called «fan subtitling», which jeopardizes the quality of subtitling on a global scale. That is why there is quite a number of works discussing different issues of subtitling. Translation of subtitles is researched in different aspects. Some works focus upon perception of the subtitles and tracking the eyes movement during watching an AV-content with subtitles (Schotter \& Rayner, 2012), (Dwyer, 2015), other researchers highlight the problems of AVT connected with conveying the meaning of the culture-specific concepts and peculiarities of trans-cultural transfer during the process of translating subtitles (Gottlieb, 1997; Tailor, 2000), a lot of attention is payed to the didactic of AVT and teaching the essential techniques of subtitling process (Sponholz, 2003; Diaz Cintas, Remael, 2008). Finnish researcher Tiina Holopainen from University of Turku presents her own model of subtitles translation strategy (Holopainen, 2010). The present research will focus upon the problems of translation of culture-specific concepts and tools of trans-cultural transfer in the process of subtitling. First, it is crucial to mention major restrictions connected with AVT overall and subtitling in particular.

\section{Basic restrictions of subtitling}

We have already mentioned that the AVT imposes on a translator certain restrictions, which are not typical for other fields of translation practice. The list of restrictions may differ according to different kinds of AVT; here we will focus upon the restrictions to be considered in the subtitling process. There are four main types of above said restrictions:

1. Normative restrictions;

2. Social restrictions;

3. Personality restrictions;

4. Physiological restrictions

Normative restrictions are based upon determining the type of equivalence to be achieved during translation. In case of AVT, it will be useful to take into consideration the classification of equivalence types determined by Nida and Taber. They define two major types of equivalence as follows: formal equivalence (formal correspondence) and dynamic equivalence. Formal equivalence is understood as a formal correspondence between an item in the target language and definite word or phrase in the source language. In the auspices of the formal equivalence, a translator tends to preserve fidelity of separate words or even phrases, grammatical and syntactical structures trying to convey the meaning of the source text words by means of the target text resources. In other words, we can say that the formal equivalence is a kind of "word-toword" translation or "text-oriented translation". Dynamic equivalence can be reached by providing the definite influence upon the target text addressee and getting the definite response, which will tend to be the same as the response of the source text addressee. The translated text should trigger the same impact upon the target text audience as the source text was meant to. This 
type of equivalence is culture-oriented and can provide an adequate response of the addressees. In can be called a "sense-to-sense" translation or "meaning-oriented" one. Dynamic equivalence is an extremely important concept for AVT, because our main goal is to provoke a reaction, a response to the translated $\mathrm{AV}$-product, which will correlate with the response to the source AV-product. We need to perform the so-called user-oriented translation whereas "the message is preserved and the translation is faithful" (Nida and Taber, 1982). On the other hand, many AV-products tend to be not only emotionally oriented, they often include a lot of cognitive information, which should be translated without any omissions or distortions, so this is where formal equivalence comes in handy.

Social restrictions underline the necessity to take into consideration cultural, moral, ethic, religious and other values of a society in question.

During translation of AV-products we also have to consider culture-specific concepts, which can be difficult for target language audience to understand, so there should be developed an appropriate approach towards translating such phenomena. Sometimes these restrictions compel the translator to transform the original text dramatically, especially when the differences in target audience's perception of AV-context occur due to some definite background knowledge, which is a part of a source culture and can be understood by default. This also concerns intertextuality in all of its forms: allusions, citation, parody, etc.

Personal restrictions of AVT emerge due to peculiarities of linguistic identity of a translator and his picture of the world, because each person sees the world through his own unique prism of worldview. It was a German scientist and philosopher Wilhelm von Humboldt who argued that a definite language engenders a definite "worldview", which influences our perception of the world. These ideas became very popular in the XX century and effected a lot of research concerning linguistic identity of a nation. There is no doubt that AVT is an act of individual creativity, so the translator's personal picture of the world overlaps the national-specific picture of the world of the nation he belongs to. This may lead to both choosing some unique variants of translation, and to making crucial mistakes.

The last, but not the least group of restrictions is connected with the form of subtitles presentation. These restrictions sometimes become major ones and oppress the process of translation and decision-making. They root in the physiology of human perception and peculiarities of mental cognitive processes connected with reception and comprehension of different types of information. Some of these restrictions have been defined by experiment, others result from subtitling practice. Some of these restrictions emerge from the code of subtitling, endorsed by the European Association for Studies in Screen Translation. According to their requirements, in the course of subtitling, we should use simple syntactic units, each subtitle should be syntactically selfcontained, and we do need to subtitle repeated or obvious names, common comprehensible phrases (Carrol and Ivarisson, 1998). All mentioned and the other subtitling rules make the views be able to read each subtitle, because the average speed of reading is estimated to be about 15 symbols per second. That is why each subtitle should consist of not more than 80 symbols for cinemas and not more than 72 symbols for TV. It means that the subtitle becomes a kind of squeezed speech. We have to omit some words and syntactical structure in order to scale the meaning to fit into the restricted amount of symbols.

More physiological restrictions set the translator of subtitles into a very limited environment. The viewer needs some time to correlate the subtitle with the image on the 
screen; there should be some natural internal rhythm in a subtitle, so it will be comfortable to read it. Sometimes one sentence can be split into several lines or even several subtitles, so the translator has to follow the meaning of the whole phrase and the images appearing on the screen. All these restrictions inevitably lead to some type of semantic compression of the source text that is why we often omit interjections, repetitions or sometimes utterances, which are decided to be semantically excessive. The translator has to generalize meaning, paraphrase the source text to squeeze it into required 72 symbols. Moreover, we need to remember, "all important written information in the images (signs, notices, etc.) should be translated and incorporated wherever possible" (Carrol and Ivarisson, 1998). It means that some symbols in a subtitle can be also "stolen" by the inserts, including the written source text, appearing on the screen. It may include some information about the person speaking, names of companies, streets, newspapers, etc., appearing in the AV-content in a written form. Nowadays it is very fashionable to incorporate into a shot some verbal images (SMS texts, email, chats, etc.). They make the film more fun to watch and more difficult to subtitle.

If the translator fails to observe all these restrictions, the result of his or her work may be poor. During last decade there appeared hundreds of poorly subtitled films and TV-series, because, on one hand, the overall quality of translation is quite low; on the other hand, amateurs, who do not even know about the above-mentioned restrictions, subtitle a lot of content. However even the experienced audiovisual translators sometimes are stuck, when they face some difficulties in a source text, connected with linguocultural aspects of language. Here we will discuss some ways to perform a trans-cultural transfer during subtitling, taking into consideration all the restrictions, described above.

\section{Subtitling as a trans-cultural transfer}

The Director of the Humanities Center at Harvard University Homi K. Bhabha called culture a strategy for survival and said that it is "both transnational and translational" (Bhabha, 1994). The development of media and cinema industry makes cultures - as sources of different values, experiences, customs or traditions - translate all these mental attitudes transnationally. Here by translation Bhabha meant not literary translation from one language to another, but translation of issues which culture signifies and which are signified by culture. Although we may state that, the most important tool of translation culture values and peculiarities on the global scale is translation from source into target language.

In the course of subtitling cultural differences, become an issue, because of globalization of cinema market and availability of diverse AVcontent via the Internet. Showing films and TVprograms in a source language accompanied with subtitles gradually becomes a worldwide practice, and the major task for a translator now is to prevent a communicative failure, which may occur during watching an AV-content made by the representatives of another cultures. Sometimes the discrepancy between the values of the source culture and attitudes of the target culture cause a king of cognitive dissonance. This is especially true for comedy movies. Very often, the comic effect of verbal and nonverbal humor requires some background knowledge of history, culture, customs and traditions. German researchers Hennig-Thurau, Walsh and Bode argue the fact that humor becomes a substantial barrier for importing Hollywood movies to Germany. They reasonably say that dubbing and subtitling reduce a movie's level of humor and, consequently, its attractiveness to movie audiences. "Accordingly, American movie comedies which refer to the specific American cultural referencing system 
of humor and are shown in a dubbed format can be expected to perform less successful in Germany than in the US" (Hennig-Thurau, Walsh and Bode, 2004). On the other hand, experts notice that China is gradually becoming a gold mine for Hollywood, because of globalization of Chinese cinemagoers' mentality and their thirst for western lifestyle. That is why China is considered now a "fertile ground for resuscitating "Hollywood flops" that fail to impress in the U.S. and European markets, citing the "unique tastes" of Chinese audiences" (Yang, 2015).

The same rules work in case of subtitling Russian movies into English. Our "mysterious Russian soul" becomes even more mysterious, when our movies are subtitled into English without taking into consideration the rules and the restrictions of subtitling. Russian cultural environment differs from the national cultures of the western world and our cinematograph is not an exception. Nancy Condee, a well-known specialist in contemporary Russian cinema, says that to be Russian is to be universal. Our culture is full of paradoxes, reflected in our movies: "to be poor in this world is to be rich in the other world; to be humble is to be great; to suffer is to be blessed" (Condee, 2009). The unique fate of our country has always been very interesting but incomprehensible for foreign viewers. That is why they are interested both in movies showing the history of imperial Russia, and in movies about contemporary Russia. In addition, the task of translator is to make these pieces understandable.

Further, we will discuss the principles of trans-cultural transfer in subtitling based on analysis of the movie "The Spy", the adaptation of the Boris Akunin's novel "The Spy Novel" (Шпионский роман). The movie is set in the USSR in the year 1941 just prior to the beginning of the Great Patriotic War. The main character, Egor Dorin, and his chief Oktyabrsky, a Major of The All-Russian Extraordinary Commission for Combating Counter-Revolution, Speculation, and Sabotage, are trying to stop Nazi's invasion of the USSR. Foreign critics called it a fantasy socialist realist film, an example of a Sots-Art, full of Communism mythology, culture-specific humor and mimicking the Soviet past. It is full of allusions to the things, places and events that are hard to understand by the foreign viewers. We will analyze the most difficult parts of the movie script and the translator's decisions made in the course of subtitling. The subtitles have been proofread and approved by the editor, so we may consider them as a reliable material for the research.

\section{Subtitling culture-specific concepts}

Culture-specific concepts usually express concepts, which are totally unknown in the target culture. They may belong to material culture or social culture may include names of different institutions, political, religious and artistic concepts and so on. Translating these concepts may become a challenge for a translator. It can be even more challenging in terms of subtitling, because culture-specific concepts impose even more restrictions. Different scientists devoted their work to categorization of culture-specific concepts and to finding the most effective translation strategies. The most complete list of translation strategies, used for dealing with culture-specific concepts, was proposed by Peter Newmark and includes the following procedures: transference (transcription or transliteration), naturalization (adaptation of the source language world), cultural equivalent (replacing a cultural word in the source language with an equivalent in the target language, though the translation may be inaccurate), functional equivalent (using of a culture-neutral word), descriptive equivalent (explanation of the culture-specific concept's meaning), componential analysis (finding a 
target language word with a similar meaning and demonstrating first their common and then their differing sense components), synonymy (finding the closest equivalent in the target language), through-translation (calque or loan translation), shifts or transpositions (changing the grammar), modulation (using dissimilar terms of the source and target languages in conformity with the current norms of the target language), recognized translation (using of official or the generally accepted translation), compensation (in case of loss of meaning in one part of a sentence it is compensated in another part), paraphrase (explaining the meaning of the culture-specific concept, the explanation is much more detailed than that of descriptive equivalent), couplets combining two different procedures) and notes (additional information in a translation) (Newmark, 1988). During analysis, we will use this list of procedures and see, which methods of translation do work in subtitling.

The movie is full of culture-specific concept, namely the concepts representing the lifestyle of the Soviet people. For example, in the very beginning of the movie we see the protagonist, Egor Dorin, boxing on a ring. $\mathrm{He}$ is showing off, missing the blows and waiting for a chance for an effective attack. His coach tries to make him fight tooth and nail and says "Берешь чемпионат Москвы - все, считай, ты уже мастер сnорта". Here we have a culturespecific concept "мастер сnорma", which has no equivalent in the English-speaking culture. The dictionary gives us two variants of translation: a recognized variant "Master of Sports", which is a calque from Russian, and a cultural equivalent "certificate of mastery". The last variant may seem a good decision, but even after a short search we may see, that it is not connected with sports. We can get the certificate of mastery in economics, education, etc. We cannot use the paraphrase or descriptive equivalent, because of physiological restrictions - we already have 32 symbols in a line. On the other hand, the image on the screen does not change for some time; we can see the coach and the boxer quite clear. It gives the translator a unique possibility to add an extra line and give a limiting word "badge". As the result, the subtitle looks like this: "Once you win | the Moscow Championship,| you'll get the Master of Sports | badge easily". We see four lines (the end of line is marked with a $\mid$ sign), each line does not exceed 36 symbols; the subtitle corresponds with the image on the screen. In this case, we were able to use a descriptive equivalent to make the subtitle more comprehensible.

When we meet in the source text the culturespecific concepts, connected with measures, sizes, etc. we follow the procedure of finding a culture equivalent. In the movie, the protagonist, Egor, becomes a secret service agent and his chief asks a very experienced warehouseman to find a set of uniform for the newcomer. The warehouseman does not need to measure Egor, he just looks at him and says “Фигура стандартная, сорок восьмой размер, третий рост. Нога у тебя, парень, сорок три?". We obviously cannot use Russian sizes and measures in subtitles, so we need to transfer them into the measures, used in the target culture. Fortunately, in subtitles we may use figures, instead of writing the numbers in words. By doing this, we may save some symbols and make our viewer read faster and understand better. The translator proposed the following variant, approved by the proofreader "Quite a standard man.| Size L, waist 33. | What's your shoes size? 9?"

The work of translator becomes more difficult, when he or she encounters the culturespecific concepts connected with culture, history of folklore. Here we need to use our creativity and find out the way to balance between different restrictions. In the movie we see the following scene - the protagonist and his chief with a 
couple of other people are on a mission, they have to astray a German spy, who is going to be air dropped in some forest outside Moscow. They come to some little suburban train station to track down the residents, who are going to meet this spy. The protagonist Egor Dorin and his boss Major Oktyabrsky are lying in ambush, Oktyabrsky sees three German residents, coming into the station building, and sings: "Три фашиста, три весельх друга, экипаж машины боевой. A третий кто?" Here we see the allusion to a famous Russian song about three tankmen, but here we may observe a strategy of contamination the word "танкиста" (tankmen) is changed to "pauиста" (Nazis). These two words do rhyme, but the meaning changes dramatically. The problem is that this song is a good example of the culture specific intertextual inclusion, which is very well known in a source culture, but is unknown for the representatives of the target culture. Moreover, contamination creates a comic effect, which can be easily lost during translation. The translator has two different variants: either to neutralize the comic effect and translate the song literary, or to find an appropriate variant of a cultural equivalent. Here we should ask ourselves a question: "Which part of the song is the most important?" The only way to understand it is to match the subtitle to the AV-context. On the screen, we see three people entering the station, so the key word here is "three". Then we need to find a song or a rhyme in the target culture, which includes the word "three" and can be squeezed into 36 symbols in a line. The translator has chosen an English nursery rhyme about three blind mice: "Three blind mice, three Nazi mice | See how they run, | who's the third one?" This rhyme is also contaminated, because in the second line the word "blind" is changed into "Nazi", so the meaning remains intact. The rhyme in the third and fourth lines (run - one) helps to create the impression of a song, because the receptors can hear the original soundtrack, where the protagonist is obviously singing.

One more challenge of the subtitling process, connected with "The Spy" movie, is translation of sovetisms - culture-specific concepts that were actual in the time of the USSR. They sometimes include such variants as "председатель колхоза"-"the head of collective farm”, “клуб железнодорожников” - "local Community Center", and others. The abovementioned sovetisms have already been included into the dictionaries, though it will be not always easy for the representatives of the target culture to understand them. That is why in some cases we need to change the meaning or, to be more exact, to generalize it, to ease the process of subtitles comprehension. Here are the examples: the protagonist, Egor Dorin, has a fight with a street gang and saves a nice girl, Nadya. She is very unusual young woman - she tries to help a gangster with a broken arm, though he has just tried to stab Egor with a knife, she does not go to the local club to watch a movie or to dance. In fact, she is coming from church having an Easter cake in her arms. Egor is astonished by Nadya and starts asking some questions, for example: "А чего это вы - комсомолка, и в иерковь xoдume?" The main problem here is the sovetism "комсомолка", which has no functional or cultural equivalent in the target language. If we use a variant "Komsomol member", we will spend six precious symbols for the word "member", but it will be still a question for the viewer: Who is a Komsomol member and why can't she go to the church? The only way here is to generalize and to use an equivalent "Communist", which will put everything straight. Therefore, we get a rather nice subtitle "And why do you go to church? | Communists never do that."

One more example of generalization is using the abbreviation KGB with an evident meaning instead of less known abbreviation 
ChK (or Cheka). The protagonist tells his girlfriend the truth that he is an agent of Soviet secret service called The All-Russian Extraordinary Commission for Combating Counter-Revolution, Speculation, and Sabotage. It is impossible to use the full name of the organization because it is too long and hard to understand. That is why we change it into KGB. On the one hand, it is historically inappropriate, because KGB was founded only in 1954, and the movie is set in 1941. On the other hand, this abbreviation is very famous and provokes a definite associative reaction of the target audience. That is why the best variant of the subtitle is as follows: " $-Я$, Надюша, сотрудник органов. - Ты чекист?" "I work for the State Security. | Are you a KGB agent?"

The last thing to be mentioned here is cultural-specific slang, used by the characters of "The Spy" movie very often. As was said earlier the movie is set in the USSR in the year 1941 just prior to the beginning of the Great Patriotic War. The main character, Egor Dorin, is trying to help a girl, who is attacked by the members of the little suburban gang. One of the ruffians says to Egor "Иди, покури, браток”, because he is relaxed and has no intention to start a fight. The first variant to translate a word "браток" is an English word "brother". However, in the context of a movie the word can be understood differently. The word "brother" has a positive connotation, it's a man close to you, friend, "a person who you are stuck being related to until the day you die through good or bad" (Urban Dictionary). The word has an obvious positive connotation, although the situation on the screen suggests an opposite situation. The second variant to choose can be a slang word "bro" and it may be quite a good variant, but here we come into conflict with the dynamic equivalence restriction. White ruffian, dressed in the "Soviet 40 s" style simply contradicts with the word "bro", used mostly by modern surfers or skaters. That is why the variant "dude" as the most neutral word which can be associated with the last century and does not inflict any other additional connotations and associations. The same work is to be done while subtitling the phrases like "Какая краля, nацаны”" - "What a chick, guys!", "Кранты тебе, падла" - "Your ass is grass, bustard". Sometimes we need to neutralize slang to make sure we do not use banned words and to ensure the viewers understand their meaning. That is why we neutralize for example the word "флакон" so it becomes just "a bottle", “кутузка" - "prison", etc.

\section{Conclusions}

Culture-specific concept, being an issue in course of the literary translation, becomes a challenge for an audiovisual translator. All problems connected with differences of the source and the target cultures are enhanced by different restrictions, connected with peculiarities of subtitling. It is up to an AV-translator to decide which procedure should be used in order to subtitle an AV-content, containing different allusions to historical events, customs and traditions, values and mental attitudes due to abundant cultural diversity. Taking into consideration the fact that AV-text is always a multi-coded one, containing not only a verbal channel, but also some nonverbal channels, including an image, music, different sounds and noises, it is always necessary to make a coherent unity of all these information channels in order to create a viewer-friendly product. We should try to get an adequate response of the target audience, which will be close to the intention of the author of the movie and to the reaction of the source audience. In case of subtitling, we have to squeeze all this into a definite amount of symbols, to ensure that our viewer will be able to read them. 
As for translation strategies, connected with the problems of cultural specificity of the source text, we cannot use such procedures as explications or giving footnotes, so popular in literary translation practices. Sometimes we have to neutralize the culture-specific concept in order to follow the restrictions described above. Sometimes it is possible to use a cultural equivalent or adapt the concept to the target culture with a slight or considerable change of the meaning. Taking into consideration the nonverbal AV-context, restrictions and rules of subtitling process, peculiarities of the source and target cultures and using a bit of imagination it is possible to create top-quality subtitles.

\section{References}

Dwyer, T. (2015). From Subtitles to SMS: Eye Tracking, Texting and Sherlock. Refractory. A Journal of Entertainment Media, available at: http://refractory.unimelb.edu.au/2015/02/07/dwyer/

Gottlieb, H. Subtitles, Translation \& Idioms. Copenhagen: Center for Translation Studies. University of Copenhagen, 1997.

Holopainen, T. (2010). Av-tekstityksen tehtävistä ja ominaisuuksista ohjautuvuuden ja toimivuuden näkökulmasta. (On the tasks and characteristics of subtitles from the point of view of guiding factors and functionality. Includes a German summary.) Unpublished thesis. Turun yliopisto, available at: http://www.doria.fi/handle/10024/66286

Jorge, D. C., Aline, R. Audiovisual Translation: Subtitling. Manchester, St. Jerome Publishing, 2007. $272 \mathrm{p}$.

Kozulyaev, A. (2014). Audiovisual translation as a teaching subject and principles of audiovisual translation teaching course curriculum building. Problems of Translation, Linguistic and Literature Studies, Series "Language. Culture. Communication. Issue 17, Nizhny Novgorod, 2014, pp. 110-116.

Nida, E. A., Taber, C.R.(1982). The Theory and Practice of Translation, Leiden: E. J. Brill.

Schotter, Elizabeth R. \& Rayner, Keith (2012). Eye movements in reading. Implications for reading subtitles. Eye tracking in audiovisual translation. 83-104.

Carroll, M., Ivarsson, J. (1998). Code of Good Subtitling Practice. Endorsed by the European Association for Studies in Screen Translation in Berlin on 17 October 1998, available at: http://www. esist.org/ESIST\%20Subtitling\%20code_files/Code\%20of\%20Good\%20Subtitling\%20Practice_ en.pdf

Bhabha, H. K. (1994). The location of culture. London and New York, Routledge, 1994. 197 p.

Hennig-Thurau, T., Walsh, G., Bode, M. (2004) Exporting Media Products: Understanding the Success and Failure of Hollywood Movies in Germany /Advances in Consumer Research, Vol. 31, 2004, available at: http://www.acrwebsite.org/volumes/v31/acr_vol31_11.pdf

Yang, L. (2015). China Must Not Remain Fertile Ground for Hollywood Flops, Published in Huanqiu (China) on 30 June 2015, available at: http://watchingamerica.com/WA/2015/07/10/chinamust-not-remain-fertile-ground-for-hollywood-flops/

Condee, N. The imperial trace. Recent Russian cinema, New York, Oxford University Press, 2009.

Newmark, P. Approaches to Translation. Shanghai Foreign Language Education Press, 2001. $200 \mathrm{p}$. 


\title{
Перевод субтитров - перевод культур
}

\author{
Е.Д. Малёнова \\ Омский государственный университет \\ им. Ф.М. Достоевского \\ Россия, 644077, Омск, пр. Мира, 55 а
}

Статья посвящена проблеме транскультурного переноса в аспекте субтитрирования как разновидности аудиовизуального перевода. Методология исследования заключается в определении основных способов перевода культурно-маркированной лексики с учетом принципов динамической эквивалентности и ограничений, сопровождающих процесс перевода субтитров. В статье подробно рассматриваются основные ограничения, о которых необходимо помнить в проиессе субтитрирования, а также раскрываются причины возникновения такого рода ограничений. Также автор обращает отдельное внимание на проблемы аудиовизуальногопереводасточкизрениятранскультурногопереноса. Врезультате определяются основные стратегии субтитрирования кинопроизведений, содержащих реалии и исторически маркированную стилистически сниженную лексику в аспекте учета свойства поликодовости аудиовизуального контента. Результаты исследования могут применяться в переводческой практике в качестве руководства к действию при переводе субтитров, а также в практике обучения аудиовизуальному переводу.

Ключевые слова: аудиовизуальный перевод, субтитрирование, реалия, язык оригинала, язык перевода, транскультурный перенос, динамическая эквивалентность.

Научная спещиальность: 10.00.00 - филологические науки. 